\title{
Black customers' perceptions of service quality in the life assurance industry
}

\author{
Merle Sandler*, Mike Bendixen \& Riri Elfassy \\ Graduate School of Business Administration, University of the Witwatersrand, P.O. Box 98, Wits, 2050 Republic of South Africa
}

Received April 1995

\begin{abstract}
With this research we sought to evaluate black customers' perceptions of service quality in the life assurance industry. Personal interviews were conducted nationwide with 165 policy holders of a company. Altogether 18 of the company's managers from various regions filled in the questionnaire for comparison purposes. The difficulties experienced in doing research in disadvantaged communities were highlighted. This could be a challenging area for future research as the specific needs of consumers in this important market are still largely unknown to marketers and service providers. The pilot study revealed that it was necessary to simplify the scales that are usually used, to phrase the questions in the terminology used by the consumer and to rescale the responses. It was established that the criteria used by black customers in the life assurance industry to assess service quality were different from those of Parasuraman, Zeithaml \& Berry but the generally held view that expectations of service quality are higher than perceptions was upheld. Cluster analysis and ANOVA revealed that perceptions of service quality varied among customers with different socio-economic backgrounds.
\end{abstract} Met hierdie navorsing is beoog om swart klante se persepsies van diensgehalte in die lewensversekeringsbedryf te evalueer.
Persoonlike onderhoude is landwyd met 165 polishouers van 'n maatskappy gevoer. Altesaam 18 van die maatskappy se
bestuurders uit verskeie streke het die vraelys vir vergelykingsdoeleindes voltooi. Die probleme wat ondervind word wan-
neer navnrsing in agtergeblewe gemeenskappe gedoen word. is uitgelig. Dit kan 'n uitdagende veld vir toekomstige navor-
sing wees, aangesien die spesifieke behoeftes van klante in hierdie belangrike mark steeds in 'n groot mate onbekend is vir
bemarkers en diensverskaffers. Die proefstudie het aan die lig gebring dat dit nodig was om die skale wat normaalweg ge-
bruik word, te vereenvoudig, om die vrae te formuleer in die terminologie wat deur die klant gebruik word, en om die ant-
woorde te herskaleer. Daar is vasgestel dat die kriteria wat deur swart klante in die lewensversekeringsbedryf gebruik word
om diensgehalte te evalueer, verskil van dié van Parasuraman, Zeihthamel \& Berry, maar die algemene siening dat ver-
wagtinge van diensgehalte hoër is as die persepsies, is gehandhaaf. Trosanaliese en VARO het aan die lig gebring dat
persepsies van diensgehalte onder klante met verskillende sosio-ekonomiese agtergronde wissel.

*To whom all correspondence should be addressed.

\section{Introduction}

In the past, quality of service was regarded by many companies, both in South Africa and worldwide, as a soft idea, an elusive goal or a low priority. In the latter part of the 1980s, this began to change and today service excellence is regarded by many managers as a key factor for success.

Life assurance is an abstract and complex service that focusses on future benefits. It is usually sold by an agent who is the primary contact person and on whose advice buyers rely in finding a suitable policy. After the sale, agents provide a follow-up service, helping customers make policy changes in response to changing needs.

The life assurance market within the black community has shown strong growth in the past few years. This growth is related to the growth in personal disposable incomes, the breakdown of the extended family, urbanization and the growing awareness of the benefits of life assurance.

At present this industry is facing numerous challenges such as the advent of the 'new South Africa', the threat of nationalization and growing pressure for socially responsible investments. Further problems facing life assurance companies are the increasing level of unemployment caused by the downturn in the economy and retrenchments in the mining industry, the growing influence of the Burial Societies and the Stokvel market' which are attracting more and more funds, and the threat by financial institutions to enter the general life assurance market.

Traditionally, insurance institutions have had a bad image in the eyes of the black community. They have based their fears and low trust level on past experiences with unreliable and commission-chasing agents or with companies that went bankrupt. It is against this background that the providers of life assurance will be forced to eradicate mediocre service and set their sights on consistently excellent service if they wish to survive.

In this research, perceptions and expectations of service quality among black customers in the life assurance industry were evaluated. It was contended that previously developed models in the area of service quality would not be applicable in an unsophisticated and disadvantaged market.

The research was broken down into the following sub-problems:

- The first sub-problem was to confirm the generally held view that customer expectations of the quality image of a service firm tend to be higher than customer perceptions.

- The second sub-problem was to segment customers into several quality groups according to their socio-economic background. This would provide firms with valuable insights for their marketing and promotional strategies.

It is recognized that the services provided by insurance institutions are multifaceted. As a consequence, customers for these services may have different expectations depending on which service they have purchased. While a generic approach to the life assurance product was the primary focus of this study, differences by benefit were explored.

\section{Literature review}

One of the primary objectives of service organizations is to be customer driven, that is to develop and provide services that satisfy the needs of customers. To achieve this, service providers need to understand how customers evaluate their services. 
A framework for isolating differences in evaluation of quality for goods and services is the one proposed by Nelson (1970) and Darby \& Karni (1 973). They identified three categories of qualities of consumer goods:

- Search qualities: attributes which a consumer can determine prior to purchasing a product.

- Experience qualities: attributes which can only be discerned after purchase or during consumption.

- Credence qualities: characteristics which the consumer may find impossible to evaluate even after purchase and consumption.

Zeithaml (1981) presented these categories as a continuum of evaluation ranging from 'easy to evaluate' to 'difficult to evaluate'. At the left end of the continuum are goods high in search qualities, easiest to evaluate even before purchase. At the right end of the continuum are services high in credence qualities, most difficult to evaluate because the consumer may be unaware of or may not have sufficient knowledge to decide whether the service satisfied his needs even after consumption.

An overlap of goods and services in the middle of the continuum includes items high in experience qualities. These may be evaluated only once they have been purchased and are being consumed.

The unique features of services, where experience and credence qualities dominate, make them more difficult to evaluate than goods. This difficulty in evaluation forces consumers to rely on different cues and processes when evaluating services.

A third framework was proposed by Schmenner (1986). It is relevant because it introduces a further key characteristic of a service business: level of Service Customization. In this model the degree to which the service is customized for the consumer is combined with the level of consumer interaction. A two-by-two Service Process Matrix was developed to categorize a plethora of diverse service businesses.

Applying the above models to the service sector being investigated, puts life assurance in the 'credence' service category. It is a quasi-professional, labour intensive service with a certain degree of consumer contact and is normally provided by for-profit organizations. It could neatly fit in the quadrant 'Professional Service' in Schmenner's Service Process Matrix.

The high labour intensity of the life assurance service presents service managers with challenges in managing and controlling staff, hiring, training, and developing methods and control procedures especially for the workforce in widespread geographic locations (Schmenner, 1986).

Lovelock (1984) suggested that there must be an ongoing effort to educate customers, keep them informed, and correct them tactfully when they make errors because, being part of the production process, they may affect quality. Service quality is also affected by components such as word-of-mouth comments, media stories, contracting-out operations, use of agents or brokers and providing services in multiple remote sites, all of which are outside the direct control of the firm.

The concept of Relationship Marketing implies that formal marketing is important not only to attract new customers but also to keep existing customers by improving the services they receive. Relationship marketing was recommended by
Crosby \& Stephens (1987) as a strategy to overcome service intangibility especially appropriate for-complex and high 'credence' services such as life assurance. Providers of this service engage in relationship-building activities that empha size buyer-seller interaction and communication.

The most substantial contribution to the concept of service quality and the factors that influence it, was made by Parasuraman, Zeithaml \& Berry during the 1980 s. The first phase of their research programme which started in 1983, resulted in the development of a conceptual model that defines service quality from the customer's viewpoint. They showed that the criteria used by customers in assessing service quality fit ten dimensions: tangibles, reliability, responsiveness, communication, credibility, security, competence, courtesy, understanding/knowing the customer, and access (Parasuraman $e$ al., 1985).

Phase II involved an empirical study that focussed on the 'customer side' of their service quality model. The outcome was the development of SERVQUAL, a methodology for measuring customers' perceptions of service quality (Parasuraman et al., 1988).

On the basis of the findings of this study, they consolidated the above-mentioned ten criteria into five independent dimensions: tangibles (physical facilities, equipment, and appearance of personnel), reliability (ability to perform the promised service dependably and accurately), responsiveness (willingness to help customers and provide prompt service), assur. ance (knowledge and courtesy of employees and their ability to convey trust and confidence), and empathy (caring, individualized attention the firm provides its customers).

Evans (1989) investigated the perceptions of service quality in a general bank with specific reference to black instalment sale clients. He conducted a qualitative study followed by a quantitative investigation with an effective sample size of 130 black male customers. He rejected the hypothesis that the conceptual model devised by Parasuraman et al. (1988) could be applied, as black consumers' service quality determinants placed greater emphasis on customer orientation, marketer behaviour, empathy and assistance. While this study explored the applicability of the findings of Parasuraman et al. (1985; 1988 ) in a South African service business, the thrust was not aimed at problems specific to the life assurance market for black consumers.

Social class has been found to be useful in segmenting markets (Martineau, 1958; Levy, 1966; Coleman \& Newgarten, 1971). Gilbert \& Kahl (1982) identified nine variables which influence social class. These are economic variables (occupation, income, wealth), interaction variables (personal prestige, association and socialization) and political variables (power, class consciousness and mobility). The synthesis of these variables led Gilbert \& Kahl (1982) to conclude that different social classes not only have distinctive values but also different consumption patterns. It therefore seems likely that black consumers of life assurance products would use different criteria to evaluate the quality of service provided, depending on social class.

This research sought to test the following hypotheses. 


\section{Hypothesis 1}

The determinants of service quality established by Parasuraman et al. $(1985,1988)$ are inappropriate among black customers in the life assurance industry.

\section{Hypothesis 2}

In the life assurance industry, black customers' expectations of service quality are generally higher than their perceptions.

\section{Hypothesis 3}

Perceptions of service quality by black customers in the life assurance industry vary amongst customers with socioeconomic differences such as language, occupation and location.

\section{Research methodology}

As a first-stage pilot study to investigate the concept of service quality, exploratory in-depth interviews with twelve black policy holders from various life assurance companies were conducted by an independent market research company. The Critical Incident Technique (CIT) was used to identify constructs of service quality applicable among black customers in the life assurance industry (Flanagan, 1954). Critical Incidents are defined as specific interactions between customers and the employees of service firms that are especially satisfying or especially dissatisfying. Hence not all service incidents are classified, but only those that customers find memorable become the fundamentally necessary factors leading to customers' dis/satisfactory evaluations.

The outcome of the exploratory investigation was analysed and compared with the findings of Parasuraman et al. (1985; 1988). The determinants of service quality uncovered in the interviews did not compare favourably with those of the SERVQUAL instrument. For example tangibles relating to the physical facilities or appearance of staff were not at all important. An adapted set of constructs was developed, based on the interviews to design a more appropriate questionnaire.

The preliminary questionnaire consisted of a set of statements regarding the expectations policy holders had of the service quality of a life insurance company and statements relating to the perceptions they had of the service they were receiving from the company they had their policy with. A special effort was made to use in the questionnaires the same words that the customers had used during the CIT process.

The respondents were required to indicate the level of importance of each of the expectations statements and their extent of agreement with the perceptions statements. It was felt that the original 7-point scale of Parasuraman et al. was too confusing and three different questionnaires were printed using 3-point, 4-point and 5 point scales.

The questionnaire was piloted on 20 policy holders. No assistance was given as the original idea was to use mailed questionnaires. Most of the respondents who were given a 3 point or 5-point scale scored the middle point and there were incidents of scoring all the points of the scale, scoring more than one point or not scoring at all. As a result of the piloting, the final questionnaire used a 4 -point scale, all negative statements were removed and the statements were not put in a random order. The questions relating to expectations appear in Appendix 1.
A further important finding of the pilot study was that mailing the questionnaire would lead to the total failure of the research. Trained interviewers who collected the data by means of personal interviews were therefore used.

The target population of this research comprised black policy holders, of at least two years standing, of a specific life assurance company. It was decided to interview approximately 150 customers countrywide using stratified sampling. The intention was that these would be selected on an as random as possible a basis, proportionate to the total number of customers per region.

Because of difficulties in accessing customers, interviewers in each region were given a computerized list with ten times the number of interviewees in that area. Although the names were generated randomly by the data processing department of the life assurance company, interviewers in the field were forced to select customers conveniently as many of them could not be reached. At the end of this process the effective sample size was 165 policy holders.

The same questionnaire was mailed to managers of the company for comparison purposes and this sample consisted of 18 managers.

The matrix of frequencies of response to each set of 26 statements was subjected to correspondence analysis in order to rescale the responses from an ordinal to an interval scale. (Bendixen \& Sandler, 1995)

The calculus of the gap between expectations and perceptions is more complex an issue than first meets the eye. The approach adopted by Parasuraman et al. (1988) is simply to differentiate between the importance (expectations) and performance (perceptions) scores. This approach allows for circumstances of 'over-delivery' when perceptions exceed expectations. This is conceptually discomforting on two grounds. Firstly, the feedback loop in the Parasuraman et al. (1988) gaps model should imply that, with time, such 'overdelivery' would only result in increased expectations. Secondly, it does not make good marketing sense to deliver a poor service per se (that is low performance scores) on less important issues.

These conceptual shortcomings can be overcome by redefining the gap between expectations and perceptions. It may be argued that a customer expects perfect delivery irrespective of how important a particular aspect of service is. Differences in expectations can thus be calculated by weighting a perfect delivery score ( 4 in this study) by its importance, that is

$$
\begin{aligned}
\text { expectation } & =\text { perfect performance } * \text { importance } \\
& =4 * E_{1} .
\end{aligned}
$$

Similarly, so as to ensure that a comparable scale is used, actual performance should be weighted by the importance of the item being assessed, that is

$$
\begin{aligned}
\text { perception } & =\text { performance } *_{\text {importance }} \\
& =\mathrm{P}_{\mathrm{i}} \mathrm{E}_{\mathrm{i}} .
\end{aligned}
$$

Thus, the gap measuring the difference between expectations and perceptions is given by:

$$
\begin{aligned}
\text { QUALGAP } & =\text { expectations }- \text { perception } \\
& =4 E_{1}-P_{1} E_{1} \\
& =E_{i}\left(4-P_{i}\right)
\end{aligned}
$$


Notice that the gap measured in this way adopts a score of zero when there is perfect delivery and a positive value otherwise. Also notice that over-delivery is not possible when the gap is measured in this way. Greater values in the gap score are associated with aspects of service that are both important and which are perceived by customers to be poor. As an example consider the following three pairs of scores $\left(E_{i}, P_{i}\right)$ : (1.4), (2.2) and (4.1). The conventional and proposed gap scores yield sharply different interpretations.

\begin{tabular}{lccl} 
& $(\mathbf{1 . 4 )}$ & $(\mathbf{2 . 2})$ & \multicolumn{1}{c}{$\mathbf{( 4 . 1 )}$} \\
Conventional gap & +3 (over & 0 (optimal) & -3 (under- \\
& delivery) & & delivery) \\
Proposed gap & 0 (optimal) & 4 (some un- & 12 (serious un- \\
& & der-delivery) & der-delivery
\end{tabular}

The QUALGAP scale was subjected to principal component factor analysis and the resulting factor scores were then used in a k-means cluster analysis. The chi-square test was used to ascertain if there was any difference amongst the demographic variables and policy benefits across the clusters.

Since the original ordinal data had been re-scaled, the testing of the second and third hypotheses used standard statistical techniques with the assumption that the populations being analyzed were normally distributed interval data.

The Paired t-test was used to test the second hypothesis, namely, that the mean of the re-scaled expectations scores was higher than the mean of the rescaled perceptions scores. The upper one-tailed test with a significance level of $5 \%$ was performed. Furthermore, separate tests were performed on the scores of policy holders and on the scores of managers for comparison.

The Unweighted Means Analysis of Variance (ANOVA) technique was used to test the third hypothesis, namely, that perceptions of service quality varied among different socioeconomic groups. Tests were performed on the factor scores found in the factor analysis using the three variables of language, occupation and office branch nearest to customer's location. A significance level of $10 \%$ was used throughout these tests and where a significant difference was found, Scheme's method of multiple comparisons was performed to ascertain which means were significantly different.

\section{Research findings}

Rescaling

The results of the rescaling on the expectations scale produced the following values:

$\begin{array}{lll}\begin{array}{l}\text { Re-scaled expectations scale } \\ \text { Scale item }\end{array} & \begin{array}{l}\text { First principal axis } \\ \text { co-ordinate }\end{array} \\ & 1.400 & 1.054 \\ \text { Irrelevant } & 1.431 & 1.000 \\ \text { Not important } & -0.065 & 3.563 \\ \text { Important } & -0.320 & 4.000\end{array}$

The re-scaled values ranged from 1 to 4 but irrelevant was rated slightly higher than not important which can be explained by the difficulties experienced by the respondents in differentiating between the two concepts. These two values are so close that they could have been combined but the use of a 4-point scale was preferred. In addition important and critical were closer together than in the original scale.
The results of the rescaling on the perceptions scale were follows:

\section{Re-scaled perceptions scale}

$\begin{array}{lll}\text { Scale item } & \begin{array}{l}\text { First principal axis } \\ \text { co-ordinate }\end{array} & \text { Re-scaled value } \\ \text { Strongly disagree } & 0.771 & 1.000 \\ \text { Disagree } & 0.641 & 1.370 \\ \text { Agree } & -0.105 & 3.493 \\ \text { Strongly agree } & -0.283 & 4.000\end{array}$

There is a clear distinction between strongly disagree/disagree and agree/strongly agree highlighting the importance of rescaling the data.

\section{Factor analysis}

Principal component factor analysis was performed on the rescaled QUALGAP values. This yielded a 7-factor solution with a cumulative explanatory power of $69.88 \%$ chosen on the basis of eigenvalues greater than 1 as well as the scree plot.

\section{Factor 1: Credibility}

\section{Statements}

The agents are trustworthy Rotated varimax factor loading

The agents keep their promises

0.8757

Agents don't cheat customers just

to get their commission

0.8468

The company is honest with its

customers

The agents are knowledgeable

These statements are all related to the credibility of the company and staff involving the company reputation and honesty, and the trustworthiness and believability of its agents. This factor is thus labelled credibility.

\section{Factor 2: Security}

Statements Rotated varimax factor loading

Policies are recognized by banks so

I can get a loan

The company contributes from pro-

fits towards social development

They allow me to borrow money

against my policy

These statements are all related to customer security through financial and social benefits. This factor is thus labelled security.

\section{Factor 3: Communication}

Statements

Rotated varimax factor loading

They up-date me with all the

information by post

They call me and give me feed-

back by post

The staff must keep in-touch with me all the time

They explain to me all the benefits

of my policy

They are able to give me professional

financial advice 
These statements are all related to keeping customers informed through continuous contact by post or by phone. They also involve explaining the service itself and its benefits in simple words so that customers can understand the trade-offs between benefits and costs. This factor is thus labelled communication. This is the only factor which is negatively loaded, that is a high positive score for this factor implies a high QUALGAP value which in turn means that there is a quality problem.

\section{Factor 4: Convenience}

\section{Statements}

Rotated varimax factor loading

The agents are able to speak my language $\quad 0.8836$

The premiums are affordable to the family $\quad 0.7017$

These statements are all related to the willingness of the company to make the service accessible to the customer in terms of affordable premiums and ease of contact with the agents. This factor is thus labelled convenience.

\section{Factor 5: Understanding}

\section{Statements Rotated varimax factor loading}

The premiums are stable and don't rise

all the time

The representatives collect premiums

personally from customers

These statements relate to understanding the customer's specific requirements in ensuring premiums stability and prompt collection. This factor is thus labelled understanding.

\section{Factor 6: Customer needs}

\section{Statements}

Provide many different policies to

suit any individual

Black agents will understand the needs

of black people

These statements are related to recognizing the customer's specific needs in terms of variation of products and services, and knowing the specific needs of black people. This factor is thus labelled customer needs.

\section{Factor 7: Responsiveness}

\section{Statements}

The staff pay great attention to claims

The company cares for its clients

They don't give hassles with claims

They treat me well and make me feel welcome

They pay out the money immediately

These statements relate to the willingness of the company to give prompt service regarding claims processing and payment, involving a service delivery system that cares for the customer. This factor is thus labelled responsiveness.

The results of the factor analysis showed that in the life assurance industry the most important factor for black customers is based on trust and honesty, followed by one based on financial security. This is understandable as people who take out a policy pay money and do not receive anything tangible in return. This service is based on promises - most of which are verbal.
The third important factor in this industry is sound communication and continuous customer contact. Life assurance is a high credence service, very abstract and complex. The low level of education of the population being investigated makes it very difficult to understand the full benefits of this service. What the customers are asking for is continuous contact with staff and agents, by mail or by telephone, so that the services can be explained to them in words they can understand. This may help reduce the perceived risk of the investment.

Factors 4, 5 and 6 mainly address the unique needs of the black community. Premiums must be affordable and stable, and they must be collected on time or the money is spent elsewhere. Considering the fact that in Natal and the Cape more than $80 \%$ of the premiums are personally collected by a company representative, this is the 'First World, Third World' dichotomization of the service delivery and production processes.

In the life assurance industry issues regarding claims handling and payment are not given top priority, as these instances do not occur frequently as in the short term insurance industry for example. This is shown by the fact that responsiveness was the last factor in order of importance.

Finally, the dimensions found in this study do not conform altogether with those found by Parasuraman et al. (1988). During all phases of the data collection it was clear that in this service sector tangibles do not play an important role in the process of evaluating service quality.

\section{Cluster analysis}

The seven factor scores obtained in the factor analysis process were used as inputs for the $\mathrm{k}$-means cluster analysis. The solution with five clusters produced the best results. The factor scores across the clusters appear in Table 1.

\section{Group 1: Customer care/credibility}

This group was highly dissatisfied with responsiveness and credibility. Both these factors are positively rated which show a big quality gap in issues such as caring for customers and knowing their requirements, 'hassle free' service, trustworthy and honest and knowledgeable agents. This group also had a slight quality problem with understanding, security and customer needs. This group was called the "Customer care/ credibility' group.

\section{Group 2: High perceived service quality}

This group was happy with issues of financial and social well being (security). Communication (negatively loaded) was also perceived to be satisfactory for this group. Generally these

Table 1 Factor scores across clusters

\begin{tabular}{lrrrrr}
\hline & Cluster 1 & Cluster 2 & Cluster 3 & Cluster 4 & Cluster 5 \\
\hline Factor 1 & 1.20853 & $0.214 \mathrm{E}-01$ & -0.44645 & -0.15811 & 0.50649 \\
Factor 2 & 0.29262 & -0.62343 & $-0.89 \mathrm{E}-02$ & 1.47996 & -0.29489 \\
Factor 3 & -0.56725 & 0.46875 & -1.54426 & 0.42649 & -0.24428 \\
Factor 4 & -0.36328 & -0.18136 & -0.17332 & 0.11720 & 3.80921 \\
Factor 5 & 0.35945 & -0.10798 & 0.31726 & -0.09188 & -0.26821 \\
Factor 6 & 0.14761 & $0.284 \mathrm{E}-01$ & -0.52879 & 0.41505 & -0.48028 \\
Factor 7 & 2.80788 & -0.14849 & -0.39456 & -0.25341 & $-0.704 \mathrm{E}-02$ \\
\hline
\end{tabular}


customers rated the factors close to zero or negative which implies that their perceptions scores are equal or greater than their expectations scores. This group was called the 'High perceived service quality' group.

\section{Group 3: Information}

The biggest problem of this group was communication. These customers had a big quality gap in the willingness of the company to keep them informed by post or by phone in the language they could understand and to explain to them the service itself and the benefits they could expect from their policies. Except for a gap in understanding, all the other factors were rated satisfactorily by this group. This group was called the 'Information' group.

\section{Group 4: Financial stability}

Unlike the previous group, these customers were satisfied with communication but they were dissatisfied with security. They were unhappy with the financial and social benefits their policy provided and they expected more from the company in terms of borrowing and provision of bank loans. They also indicated that there was a slight quality problem regarding customer needs and convenience. This group was called the 'Financial stability' group.

\section{Group 5: Accessibility}

This group had a major problem with convenience. This factor received the highest average score which shows that the expectations are far greater than the perceptions in issues such as 'affordable premium' and 'agents that can speak my language'. This group was mainly concerned with the approachability of the agents and easy access to the service. Credibility and communication were also perceived to be a problem by this group. This group was called the 'Accessibility' group.

The distribution of respondents amongst the clusters appears in Table 2.

No statistical difference at a $5 \%$ significance level was found amongst the following variables and policy benefits across the five clusters: age, premium, year (in which policy was taken out), double accident plan, ability to borrow

Table 2 Respondent's distribution by cluster

\begin{tabular}{lccccc}
\hline & Cluster 1 & Cluster 2 & Cluster 3 & Cluster 4 & Cluster 5 \\
\hline Customers & 13 & 78 & 31 & 38 & 5 \\
Managers & 0 & 15 & 2 & 0 & 1 \\
\hline
\end{tabular}

Table 3 Probability level

\begin{tabular}{lc}
\hline & Probability level \\
\hline Office/region & 0.0000 \\
Language & 0.0000 \\
Occupation & 0.0022 \\
Education/university plan & 0.0015 \\
Death cover & 0.0000 \\
Retirement plan & 0.0050 \\
Hospital expenses & 0.0480 \\
\hline
\end{tabular}

money, unemployment plan, disability cover, funeral expense and 'cool-off period'.

The following variables and benefits showed significant differences across the five groups as shown in Table 3.

Policy holders in the Customer care/credibility group, cluster 1 , were mostly from the Johannesburg region and the largest language groups were Zulu and Tswana. Professionals were dominant but this group also included the more educated people (supervisors, students and clerks) and their most important benefit was education/university plan.

The High perceived quality group, cluster 2 (the largest group, containing $47.3 \%$ of the respondents) was dominated by policy holders in Durban and Pretoria who were mostly English speaking. The majority were from the unemployed group (including pensioners and housewives) but professionals and domestics were well represented. Their preferred benefits were death cover and retirement plan.

The Information group, cluster 3, included customers mainly from Durban, Pietermaritzburg and Cape Town who were mostly Zulu and English speaking. The major occupation groups were the professionals and drivers and the benefits preferred were education/university plan, death cover and retirement plan.

The Financial stability group, cluster 4 was the second largest group. It was dominated by customers from Johannesburg who were mostly Zulu and Tswana speaking. They were predominantly lower income customers (domestics, clerks, drivers, students and unemployed people) and their preferred benefits were death cover and education/university plan.

The fifth cluster, the Accessibility group, was the smallest group consisting of precisely five customers.

\section{Hypothesis testing}

The second hypothesis stated: in the life assurance industry, black customers' expectations of service quality are generally higher than their perceptions.

Summarized results of the tests are presented in Table 4.

Policy holders rated Expectations significantly higher than Perceptions for 18 of the 26 statements. This result is in line with the findings of Parasuraman et al. (1988) who found this trend to be consistent, irrespective of the service category. Considering that the measuring scale was only $1-4$, the reason for this could be because Expectations are extremely high and not because there is a problem in the perceived quality of service. This is confirmed by the results of the cluster analysis which indicated that more than $65 \%$ of the respondents were satisfied with the quality of service provided.

Managers rated Expectations significantly higher than Perceptions for only nine of the statements. This is reinforced by the fact that most of the mangers belonged to Cluster 2 , the High perceived quality group.

The third hypothesis stated: perceptions of service quality by black customers in the life assurance industry vary amongst customers with socio-economic differences such as language, occupation and location.

Means of the following eight language groups were compared: Zulu, English, Tswana, Afrikaans, Xhosa, Sotho, Northern Sotho and 'others'. The eleven occupation groups were domestic, student, supervisor, clerk, professional, security, driver, unemployed, selling, medical, and company 
Table 4 Summarized t-test results

\begin{tabular}{|c|c|c|c|c|c|c|c|c|c|}
\hline \multicolumn{5}{|c|}{ Policy holders } & \multicolumn{5}{|c|}{ Managers } \\
\hline $\mathrm{E}_{\mathrm{i}}$ & Mean & $P_{1}$ & Mean & Prob. & $\mathrm{E}_{1}$ & Mean & $\mathbf{P}_{\mathrm{i}}$ & Mean & Prob. \\
\hline El & 3.58 & $\mathrm{Pl}$ & 3.45 & 0.0153 & $\mathbf{E l}$ & 3.83 & $\mathbf{P l}$ & 3.48 & 0.0945 \\
\hline E2 & 3.58 & $\mathbf{P 2}$ & 3.38 & 0.0010 & E2 & 3.88 & $\mathbf{P} 2$ & 3.14 & 0.0032 \\
\hline E3 & 3.60 & P3 & 3.46 & 0.0070 & E3 & 3.90 & P3 & 2.65 & 0.0001 \\
\hline E4 & 3.60 & P4 & 2.40 & 0.0004 & E4 & 3.66 & P4 & 2.20 & 0.0000 \\
\hline E5 & 3.57 & P5 & 3.36 & 0.0005 & E5 & 3.78 & P4 & 3.53 & 0.0001 \\
\hline E6 & 3.62 & P6 & 3.41 & 0.0000 & E6 & 3.88 & P6 & 2.77 & 0.0000 \\
\hline E7 & 3.00 & P7 & 3.38 & 1.0000 & E7 & 2.42 & P7 & 3.02 & 0.9437 \\
\hline E8 & 3.33 & P8 & 3.58 & 0.9999 & E8 & 3.33 & P8 & 3.58 & 0.8847 \\
\hline E9 & 3.59 & Pq & 3.49 & 0.0107 & E9 & 3.59 & P9 & 3.52 & 0.3006 \\
\hline E10 & 3.58 & P10 & 3.52 & 0.0806 & E10 & 3.61 & P10 & 3.63 & 0.5477 \\
\hline E1I & 3.58 & PII & 3.48 & 0.0179 & E11 & 3.71 & P11 & 3.49 & 0.0571 \\
\hline E12 & 3.58 & $\mathrm{P} 12$ & 3.38 & 0.0006 & E12 & 3.88 & P12 & 3.77 & 0.0772 \\
\hline E13 & 3.58 & P13 & 3.28 & 0.0000 & E13 & 3.35 & P13 & 3.66 & 0.9311 \\
\hline E14 & 3.59 & P14 & 3.30 & 0.0000 & E14 & 3.44 & P14 & 3.60 & 0.7788 \\
\hline E15 & 3.53 & P15 & 3.45 & 0.0745 & E15 & 2.59 & P15 & 3.11 & 0.9101 \\
\hline E16 & 3.59 & P16 & 3.58 & 0.3936 & E16 & 3.54 & P16 & 3.60 & 0.6004 \\
\hline E17 & 3.14 & P17 & 3.16 & 0.6110 & E17 & 1.16 & P17 & 2.48 & 0.9999 \\
\hline E18 & 2.88 & P18 & 3.13 & 0.9982 & E18 & 1.44 & P18 & 3.25 & 1.0000 \\
\hline E19 & 3.53 & P19 & 2.88 & 0.0000 & E19 & 3.18 & P19 & 2.31 & 0.0162 \\
\hline E20 & 3.56 & $\mathbf{P} 20$ & 2.87 & 0.0000 & E20 & 3.30 & P20 & 2.67 & 0.0260 \\
\hline E21 & 3.59 & $\mathbf{P} 21$ & 3.17 & 0.0000 & E21 & 3.76 & P21 & 2.93 & 0.0015 \\
\hline $\mathbf{E 2 2}$ & 2.89 & P22 & 2.80 & 0.2261 & E22 & 1.01 & P22 & 2.06 & 0.9997 \\
\hline E23 & 3.56 & $\mathbf{P} 23$ & 2.88 & 0.0000 & E23 & 3.10 & $\mathbf{P} 23$ & 2.19 & 0.0022 \\
\hline E24 & 3.39 & $\mathbf{P} 24$ & 2.72 & 0.0000 & E24 & 2.88 & P24 & 3.55 & 0.9829 \\
\hline E25 & 3.52 & $\mathbf{P} 25$ & 2.65 & 0.0000 & E25 & 3.35 & P25 & 3.58 & 0.8380 \\
\hline E26 & 3.17 & P26 & 2.59 & 0.0000 & E26 & 2.17 & P26 & 2.53 & 0.9020 \\
\hline
\end{tabular}

manager. The nine location groups were Johannesburg, Pretoria, Florida, Germiston, Pietermaritzburg, Durban, Verulam, Cape Town and Brokers. The results are summarized in Table 5.

As far as credibility is concerned, it was shown that for occupation, company managers felt that there was a definite quality problem while customers indicated a certain satisfaction with service quality for this factor. This is another case where Gap 1, the Consumer expectation-management perception gap, found by Parasuraman et al. (1985) manifests itself in this study.

As far as security is concerned English and Afrikaans speaking customers were significantly more satisfied than customers from the Zulu, Tswana, Xhosa and Sotho groups. This was further confirmed by the location variable. Here it was found that customers in Cape Town and Natal were significantly more satisfied than customers in Johannesburg and Pretoria. When considering the occupation variable the raw data indicated that the professional and perhaps more educated customers are more satisfied than the others. The reason is probably that these customers are from higher income levels and perceive themselves to be financially secure. The managers were also satisfied with the service in this category.
Table 5 Demographic variations

\begin{tabular}{lccc}
\hline Factor & Language & Occupation & Location \\
\hline Credibility & $\times$ & $\times$ & $\times$ \\
Security & $\times$ & & $\times$ \\
Communication & & $\times$ & $\times$ \\
Convenience & $\times$ & & \\
Understanding & & & $\times$ \\
Customer needs & $\times$ & $\times$ & $\times$ \\
Responsiveness & & & \\
\hline
\end{tabular}

Looking at the communication factor the analysis showed that customers from the Pietermaritzburg region have a definite problem with the quality of service in this category.

With regard to the convenience factor, statistically different groups were found for all three variables. It was found that customers from the Zulu speaking group were definitely more satisfied with service quality in this category than people from the Tswana and 'others' groups. People from the security group are specifically unsatisfied with the service in this category. It was shown that customers in the Pretoria area are definitely unhappy with convenience. This is further 
supported by the cluster analysis which showed that $80 \%$ of the 'Accessibility' cluster came from Pretoria.

For the factor understanding there were no significant differences. This means that the perceptions of service quality in this category are similar for customers across all language, occupation and location groups.

With the customer needs factor the significant differences were between customers from Florida and customers from Pietermaritzburg.

For the last factor, responsiveness, perceptions of service quality were different amongst customers from different regions and occupation groups. Managers' perceptions of the quality of service was higher than the perceptions of the majority of the customers.

Thus the third hypothesis is supported.

\section{Discussion}

The criteria used by black customers in the life assurance industry to assess service quality were different from those established by Parasuraman et al. $(1985 ; 1988)$ but the generally held view that expectations of service quality are higher than perceptions was upheld. However, the factors that emerged do fit well with the framework proposed by Armistead (1989). Armistead proposed three 'firm' and three 'soft' dimensions of customer service, namely

$\begin{array}{ll}\text { Firm } & \text { Soft } \\ \text { Framework of time } & \text { Style } \\ \text { Fault-freeness } & \text { Steering } \\ \text { Flexibility } & \text { Safety }\end{array}$

The first factor identified in this study was credibility. The statements that load onto this factor correspond closely to the aspects of trust and confidence embodied in the safety dimension. The second factor of security relates to the ability of the customer to use life assurance for the purposes of financial leverage. This fits with the flexibility dimension. The third factor, communication, is concerned with keeping the customers updated with correct information about their policies. This corresponds to the correctness of information on the fault-freeness dimension and clarity of service on the steering dimension. Factor four, convenience, and factor five, understanding, encapsulate the perceived value and acces-sibility of the style dimension. Factor six, customer needs, relates to the 'customerization' of services under the flexibility dimension. The last factor, responsiveness, concerns the appropriateness of attitudes under the style dimension as well as the reaction time under the framework of time dimension. It is interesting to note the considerable emphasis that black customers place on the 'soft' rather than the 'firm' dimensions .

The cluster analysis conducted resulted in five distinct market segments. It is purely an empirical result which may be of interest to purveyors of life assurance services in the black market. The results indicate that there are strong differences by benefit for example education/university plan, death cover, etc. This implies that different marketing strategies and service delivery mechanisms should be applied for the different benefits. This corresponds to Fisk's (1981) recommendation of treating products as a 'bundle of benefits'.

In addition there are demographic differences (language, occupation and region) across segments. This confirms that in this market social class is 'continuing to be significant - as shaper of consumer goals, as influence on marketplace choice' (Coleman, 1983: 279).

\section{Conclusions}

The difficulties experienced in doing research in disadvantaged communities have been highlighted. This could be a challenging area for future research as the specific needs of consumers in this important market are still largely unknown to marketers and service providers. The pilot study was invaluable. It was definitely necessary to simplify the scales that are usually used, to phrase the questions in the terminology used by the consumer and to rescale the responses.

Customers were segmented into several perceived quality groups. These important results have to be considered by firms during their short- and long-term marketing and strategic planning.

\section{Suggestions for future research}

The 26-item scales, the QUALGAP scale and the proposed seven criteria may be used as a conceptual framework for further empirical study involving a bigger sample of customers from the major companies offering life assurance services in South Africa. The purpose of such a study would be to develop a standard instrument to measure perceptions of service quality in the local life assurance industry in general. The specific characteristics of the market studied, make it impossible to use a model such as the one developed by Parasuraman et al. (1985, 1988). Their model was developed in a market consisting of sophisticated customers and there is no reason to assume that such an instrument is truly universal across cultural and socio-economic barriers.

\section{Note}

1. A common practice among urban blacks has been to contribute money to a burial society as a form of self insurance. These societies are informal arrangements within very small communities or neighbourhoods. This concept has grown into that of Stokvels where contributions are used for emergencies other than funerals or for the purchase of major items such as appliances.

\section{References}

Armistead, C.G. 1989. 'Customer service and operations management in service businesses', The Services Industries Journal, Vol. 9, No. I: 247-260.

Bendixen, M.T. \& Sandler, M. 1995. 'Converting verbal scales to interval scales using correspondence analysis', Management Dynamics - Contemporary Research, Vol. 4, No. 1: 31-49.

Coleman, R.P. \& Newgarten, B.L. 1971. Social status in the city. San Fransisco: Jossey-Bass.

Coleman, R.P. 1983. 'The continuing significance of social class in marketing', Journal of Consumer Research, 265-280pp.

Crosby, L.A. \& Stephens, N. 1987. 'Effects of relationships marketing on satisfaction, retention, and prices in the life insurance industry', Journal of Marketing Research, Vol. XXIV: 404-411.

Darby, M.R. \& Karni, E. 1973. 'Free competition and the optimal amount of fraud', Journal of Law and Economics, Vol. 16 (April): 67-86.

Evans, G.C. 1989. Perceptions of service quality in a general bank. Unpublished MBA research report. Johannesburg: University of the Witwatersrand. 
Fisk, R.A. 1981. 'Toward a consumption/evaluation model for services'. In Donnelly, J.H. \& George, W.R. (eds.). Marketing of services. Chicago: American Marketing Association, 191-195pp.

Flanagan, J.C. 1954. 'The critical incident technique', Psychological Bulletin, Vol. 51, July: 327-357.

Gilbert, D. \& Kahl, J.A. 1982. The American class structure: a new synthesis. Homewood, II: The Dorsey Press.

Levy, S. 1966. 'Social class and consumer behavior'. In Newman, J.W. (ed.). On knowing the consumer. New York: John Wiley and Sons, 146-160pp.

Lovelock, C.H. 1984. Managing the customer mix in services marketing: test, cases and readings. Englewood Cliff, New Jersey: Prentice Hall.

Martineau, P. 1958. 'Social classes and spending behaviour', Journal of Marketing, Vol. 23: 121-130.

Nelson, P. 1970. 'Information and consumer behaviour', Journal of Political Economy, Vol. 78 (Jan-June): 311-329.

Parasuraman, A., Zeithaml, V.A. \& Berry, L.L. 1985. 'A conceptual model of service quality and its implications for future research', Journal of Marketing, Vol. 49: 41-50.

Parasuraman, A., Zeithaml, V.A. \& Berry, L.L. 1988. 'SERVQUAL: a multiple-item scale for measuring customer perceptions of service quality', Journal of Retailing, Vol. 64: 12-40.

Schmenner, R.W. 1986. 'How can service businesses survive and prosper?', Sloan Management Review, Spring: 21-32.

Zeithaml, V.A. 1981. 'How consumer evaluation processes differ between goods and service'. In: Donnelly, J.H. \& George, W.R. (eds.). Marketing of senvices. Chicago, American Marketing Association, 186-190pp.

\section{Appendix I}

Expectations of service quality

El: Life Insurance firms must be well established so they don't go insolvent.

E2: A Life Insurance company must be honest with its customers.

E3: The agents of Life Insurance companies must be trustworthy.
E4: The agents must be knowledgeable.

E5: The agents must keep their promises.

E6: The agents must not cheat customers just to get their commissions

E7: The agents must be Black to understand the needs of Black people.

E8: The agents must be able to speak my language.

E9: The staff of a Life Insurance company must not discriminate.

E10:Life Insurance companies must care for their clients.

El1: They must treat me well and always make me feel welcome.

E12: Life Insurance companies must pay great attention to claims.

E13: They must pay out the money immediately.

El4: They must not give hassles with claims.

El5: They have to provide many different policies to suit any individual.

El6: The premiums must be affordable to the family.

E17: The premiums must be stable and not rise all the time.

El8: The representatives must collect premiums personally from customers.

E19: The company must keep in-touch with me all the time.

E20: They must always up-date me with all the information by post.

E21: They must explain to me all the benefits I get from the policy.

E22: They must call me and give me feedback all the time by phone.

E23: They must be able to give me professional financial advice.

E24: They must allow me to borrow money against my policy.

E25: Their policies must be recognized by banks so I can get a loan if I need it.

E26: They have to contribute from profits towards social development projects. 